\title{
THE IMPACT OF CASSYTHA FILIFORMIS BUTANOL FRACTION TO THE PREGNANCY AND
} FETAL DEVELOPMENT ON MICE

\author{
ARMENIA NAZAR*, FIRLICIA AYUNING, ALMAHDY AHMADIN \\ Department of Pharmacology and Clinical Pharmacy, Faculty of Pharmacy, University of Andalas, Padang, Indonesia. \\ Email: armenia@phar.unand.ac.id
}

Received: 19 February 2019, Revised and Accepted: 14 March 2019

\section{ABSTRACT}

The impact of Cassytha filiformis butanol fraction to the pregnancy and fetal development had been conducted. The fertilized mice were treated with butanol fraction of $C$. filiformis at doses of $2.5 ; 5 ; 10$; and $20 \mathrm{mg} / \mathrm{kg}$ of body weight (BW) orally for 5 consecutive days during first, second, and third periods of pregnancy. Parent BW was monitored and the fetal number, BW, death and/or resorptive site and defect were measured. ANOVA followed by Duncan multiple range test (significance at $\mathrm{p}<0.05$ ) was performed to analyze data. The parent weight was reduced according to fraction dose and the period of pregnancy and the interaction of those factors $(\mathrm{p}<0.01)$. Only one mouse treated during the first period became pregnant with less fetus number $(\mathrm{p}<0.05)$ but all of treated during the second and third period but death, resorptive site and underdeveloped fetus were found. These indicated the butanol fraction of $C$. filiformis produced infertility and slowed pregnancy development and produce fetal defect on mice.

Keywords: Cassytha filiformis, Pregnancy development, Fetal number, Death, Fetal defect.

(c) 2019 The Authors. Published by Innovare Academic Sciences Pvt Ltd. This is an open access article under the CC BY license (http://creativecommons. org/licenses/by/4. 0/) DOI: http://dx.doi.org/10.22159/ijap.2019.v11s5.T1010

\section{INTRODUCTION}

The world is witnessing an unprecedented growth in the usage of herbal products. India, for example, is a mother hub for natural herbbased science [1]. Since 2007, Indonesian government has released a regulation for the traditional medicine policy to develop and increase their quality, safety, and efficacy [2]. Unfortunately, the number of marketed herbal products still limited. To support the government policy, we intended to elaborate our natural resources to get some valuable herbal medicines.

Cassytha filiformis is among Indonesian traditional medicine that needs scientific approved to increase its grade to be a phytopharmaca. This Lauraceae family is a parasite on a variety of plants, such mango (Mangifera indica), clove (Eugenia aromatica), nutmeg (Myristica fragrans), avocado (Persea americana), and others [3]. It contains bioactive compounds, such as alkaloids, phenol, saponin, flavonoids, terpenoids, and tannin $[4,5]$.

Conventionally, C. filiformia is used to treat jellyfish bites, to induce childbirth, anticancer [3]. Scientific researches described that this plant produced antitrypanosomal activity [5], and antibacterial [6], while our previous study indicated that this plant produced an anti-hypertension effect [7,8] anticoagulant [9], antipyretic, and analgesic activities [10]. In addition, antidiabetes [11,12], vasorelaxant [13], antioxidant, and hepatoprotection [14] also have been reported.

Besides some advantages, all herbal drugs are not safe; some may be poisonous or may cause allergenic reactions [15] or effect to one with gestation, both to the mother and the fetus [16]. C. filiformis is slightly toxic and produced delayed toxicity [17], reversible toxic to the liver [18], but both ethyl acetate and butanol fractions are irreversibly toxic to the kidney [19].

These research objectives are to evaluate the impact of $C$. filiformis butanol fraction to the development of pregnancy and fetus on mice. This is done to develop safe herbal medicines as required by the WHO 2014-2023 policy [20].

\section{METHODS}

The fraction was made from the $C$. filiformis herbs that were collected from the area of Padang city (identification was made by Andalas University Herbarium, Padang, Indonesia No. 0912/K-ID/ANDA/2011).

The study protocol was approved by the Andalas Animal Ethics Committee (approval number: 323/KEP/FK/2018). A total of 36 pregnant female white mice (indicated by vaginal plug) were divided into four groups consisting of one control group and three other groups treated with C. filiformis fraction orally at doses of $2.5,5$, and $10 \mathrm{mg} / \mathrm{kg}$ of body weight (BW) for 5 days during the first, second, and third trimesters of pregnancy. On day 18, the animals were killed and the laparotomy was made to measure the fetal number, weight, and fetal defect. The fetal defect was measure after they were fixed in Bouin and red alizarin solutions (Taylor et al., 2005). The parent BW was observed during the experiment. Data of parents' BW were analyzed by three-way ANOVA while others were analyzed by two-way ANOVA. These analyses were followed by Duncan's multiple range test with a $95 \%$ confidence interval.

\section{RESULTS AND DISCUSSION}

Results

Parent BW was significantly $(\mathrm{p}<0.001)$ affected by the period of treatment, dose of fraction and the duration of pregnancy and the interaction of those factors (Fig. 1).

The average change of BW of pregnant mice treated with the fraction during the first period was lower, compared to those treated during the second and third periods of gestation. The reduction of the BW was also dose-dependent $(\mathrm{p}<0.01)$. In this situation, the development of pregnancy of mice treated with the butanol fraction of $C$. filiformis at $2.5 \mathrm{mg} / \mathrm{kg}$ BW during the period 1 and $5 \mathrm{mg} / \mathrm{kg}$ during the period 2 of gestation was faster than the other treated group at the same period. The development of pregnancy during the third period of gestation was almost equal in all group. In addition, all mice showed some progress in weight development day by day, during 18 days of the experiment. The average percentage changes in the parent BW of control group, and the butanol fraction treated group during the first, second, and third periods of pregnancy, as seen in Fig. 1. 
Butanol fraction of $C$. filiformis dose and the period of treatment significantly influence the number of the fetus of mice $(\mathrm{p}<0.01)$, but not the interaction of these factors $(p>0.1)$. In general, the number of the fetus in the treated animal was less than those of the control group. In addition, there was no significant difference in the number of the fetus between mice treated with the different doses $(p>0.1)$. The average number of the fetus of mice treated with butanol fraction of $C$. filiformis during period 1 was greater compared to those treated during the periods 2 and 3, but the number of the fetus of mice on average between periods 2 and 3 was not significantly different. The average number of the fetus of control mice remained higher than all treated animals (Fig. 2 and Table 1).

Fetal BW of $C$. filiformis butanol fraction treated animal was significantly affected by dose, the period of treatment and interaction of these two factors $(p<0.001)$. The average fetal BW on mice treated with butanol fraction was higher compared to those of control group, and the average of fetal BW treated during period 1 of gestation was less than those treated during period 2 and 3. In this situation, fetal BW of animal treated at a dose of $2.5 \mathrm{mg} / \mathrm{kg}$ of butanol fraction of $C$. filiformis during period 1 and 3 was lower compared to those treated during period 2 (Fig. 3 and Table 2).

There was no fetal defect found on all treated mice, except resorptive sites was found on the mice treated with $5 \mathrm{mg} / \mathrm{kg}$ of fraction and one dead fetus at a dose of $2.5 \mathrm{mg} / \mathrm{kg}$ and retarded fetus of the mother treated during the second period of gestation.

\section{DISCUSSION}

These experimental study objectives are to determine the impact of the butanol fraction of $C$. filiformis to mice during gestation period at the effective therapeutic repeated doses. The treatment was made such of gestation to determine whether it produces an adverse effect in that different gestational situation.

Before being treated, mice were acclimatized for 10 days to familiarize the animals with the experimental conditions and avoid the stress that could affect the final results of the study [21,22]. The nullipara female mice were used to obtain more fetus number [23]. Those animals have regular estrus cycles, to assured animal pregnancy when they are mated [24]

As noted everywhere, certain drug can produce an adverse effect on individuals during pregnancy, both to the mother and the fetus [25]. This study provides scientific information about the impact of $C$. filiformis butanol fraction to the pregnant mice, both to the parent and the fetus.

The observation showed that most of the matted mice treated with the butanol fraction of $C$. filiformis in the first period of pregnancy were not

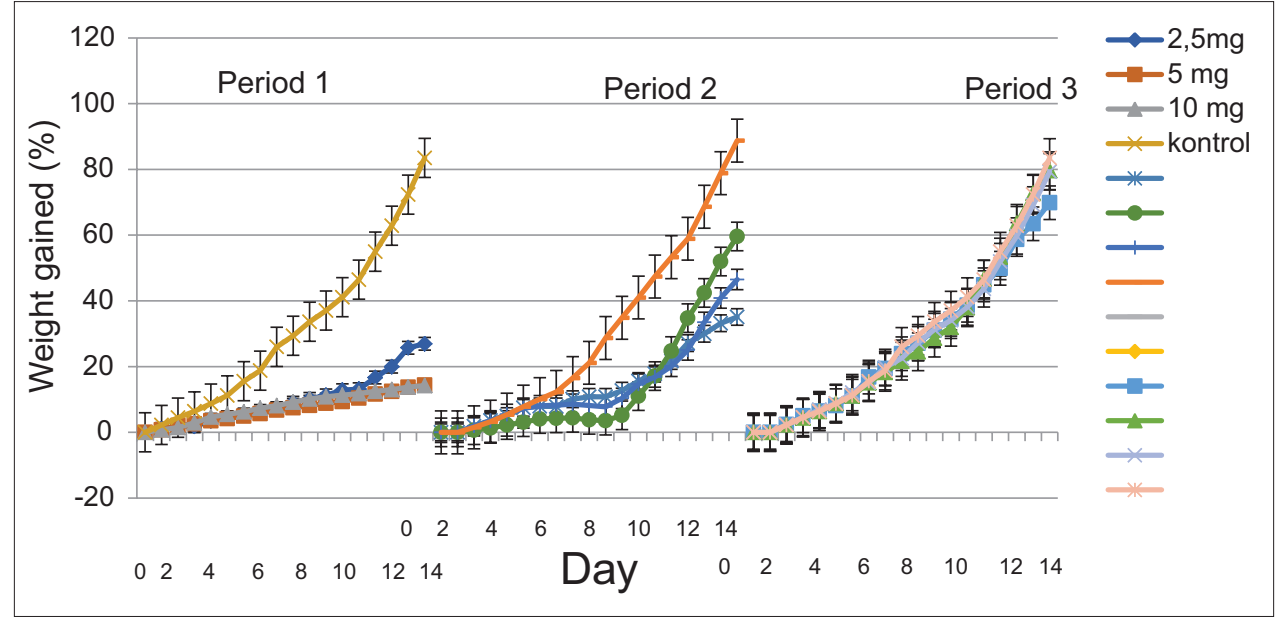

Fig. 1: The impact of butanol fraction of Cassytha filiformis to parent body weight on mice

Table 1: Fetal number of mice treated with butanol fraction of Cassytha filiformis

\begin{tabular}{|c|c|c|c|c|}
\hline \multirow[t]{2}{*}{ Doses mg/kg } & \multicolumn{3}{|c|}{ Average fetal number of mice treated during periods of pregnancy } & \multirow[t]{2}{*}{ Average } \\
\hline & 1 & 2 & 3 & \\
\hline Control & $16.000 \pm 0.943$ & $15.000 \pm 0.943$ & $14.000 \pm 0.943$ & $15.000 \pm 0.544^{b}$ \\
\hline 2.5 & $14.000 \pm 1.633$ & $8.000 \pm 0.943$ & $10.000 \pm 0.943$ & $10.667 \pm 0.703^{a}$ \\
\hline 5 & & $11.667 \pm 0.943$ & $10.667 \pm 0.943$ & $11.167 \pm 0.667^{\mathrm{a}}$ \\
\hline 10 & & $10.667 \pm 0.943$ & $10.000 \pm 0.943$ & $10.333 \pm 0.667^{\mathrm{a}}$ \\
\hline Average & $15.000 \pm 0.943^{b}$ & $11.333 \pm 0.471^{\mathrm{a}}$ & $11.167 \pm 0.471^{a}$ & \\
\hline
\end{tabular}

Data are expressed as mean \pm SEM. Average data with different superscript are significantly different $(\mathrm{P}<0.05)$.

Table 2: Fetal body weight of Cassytha filiformis butanol fraction treated mice

\begin{tabular}{|c|c|c|c|c|}
\hline \multirow[t]{2}{*}{ Doses (mg/kg) } & \multicolumn{3}{|c|}{ Average fetal body weight (gram) of mice treated during periods } & \multirow[t]{2}{*}{ Average } \\
\hline & 1 & 2 & 3 & \\
\hline Control & $0.736 \pm 0.012$ & $0.741 \pm 0.012$ & $0.834 \pm 0.013$ & $0.770 \pm 0.007^{\mathrm{a}}$ \\
\hline 2.5 & $0.839 \pm 0.022$ & $1.213 \pm 0.017$ & $1.147 \pm 0.015$ & $0.996 \pm 0.011^{c}$ \\
\hline 5 & & $0.812 \pm 0.014$ & $0.951 \pm 0.015$ & $0.883 \pm 0.010^{\mathrm{b}}$ \\
\hline 10 & & $0.800 \pm 0.015$ & $0.904 \pm 0.015$ & $0.868 \pm 0.010^{\mathrm{b}}$ \\
\hline Average & $0.787 \pm 0.013^{\mathrm{a}}$ & $0.892 \pm 0.007^{b}$ & $0.915 \pm 0.007^{c}$ & \\
\hline
\end{tabular}

Data are expressed as mean \pm SEM. Average data with different superscript are significantly different $(\mathrm{P}<0.05)$ 


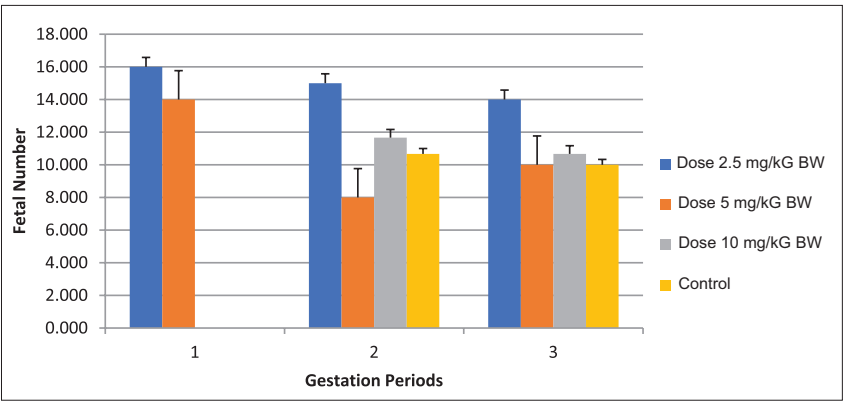

Fig. 2: The impact of butanol fraction of Cassytha filiformis to the fetal number on mice

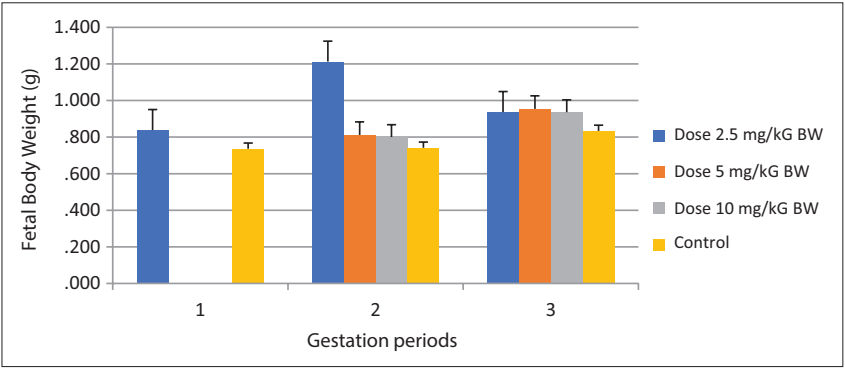

Fig. 3: The impact of butanol fraction of Cassytha filiformis to fetal weight on mice

pregnant, except one of three mothers those treated with the lowest dose $(2.5 \mathrm{mg} / \mathrm{kg})$ which was where pregnant with 14 fetuses.

Mammalian fetal development passes through three main phases: Blastocyst formation, organogenesis, histogenesis, and maturation of function [26]. According to Sadler [27], during the first trimester of pregnancy, the morula phase, zygote is continuously divided, which produce two groups of cells. One cell group will become embryo's body, and the other becomes complementary cells, which include the trophoblast, periblast, and auxiliary cells. These cells protect the embryo and make contact between the embryo and the parent. Many teratogens have the ability to inhibit this division and kill embryo, which was involved in blastocyst formation. However, most of the time the embryo survives; its subsequent development does not generally seem to be compromised $[28,29]$. That is why, when a cytotoxic compound is given during the first period of pregnancy, it will affect cell division and the morula phase formation, and thus disrupted the formed fetus as seen in this study, since $C$. filiformis contain cytotoxic compounds [4].

On the other hands, all animals treated with the fraction during the second trimester of pregnancy were pregnant, but with slower development. It is indicated by a slower increase of the parent BW, especially those treated with a higher dose $(10 \mathrm{mg} / \mathrm{kg} \mathrm{BW})$ of the fraction. The similar situation also shown by the animal treated with a lower dose of $C$. filiformis during the first period of pregnancy.

Our previous study showed that the butanol fraction of $C$. filiformis caused a decrease of food intake associated with central nervous system depressant and muscle relaxant effects on mice and thus decrease the mice BW [17]. When the compound is given to the pregnant individual, such as mice in this study, similar response may be produced. When the mother feed intake is lower, the fuel needs of the fetus will also unfulfilled, and thus, fetal development will become slower. If both mother and fetus BW gain progress are slower, they will lead to a lower average parent BW, as seen in this study. This is in agree with [29] that poor maternal nutritional intake after the periconceptional period of pregnancy can negatively impact fetal genetic growth trajectory and can result in fetal growth restriction. Similarly, Vonnahme et al. [30] also describe that maternal undernutrition on the vascularity of nutrient transferring tissue during different stages of pregnancy effect pregnancy development.

Furthermore, there was no bone abnormality seen under the red alizarine neither with Bouin's solution on the embryo fixation. The eyes, ears, feet, toes, tail, and the cleft palate seemed anatomically complete and normal. Unfortunately, the fetus of the mice treated with the $2.5 \mathrm{mg} / \mathrm{kg} \mathrm{BW}$ during the second period of gestation grew slowly, and one of them found died. A similar result also found in three of fetus where the parent was treated with $5 \mathrm{mg} / \mathrm{kg}$ BW of the fraction. In addition, there was a resorptive site on the mice treated during the second period of gestation.

Many chemicals have the ability to penetrate animal tissue and developing fetus, negatively impacting the reproductive health of human [25,31]. According to several authors $[28,31,32]$, fetuses are very susceptible to teratogenic compounds during the second trimester, also called the critical period of pregnancy. During this period (organogenesis phase), the eyes, brain, heart skeletal, urogenital, and other organs are formed. If the fetus defects, this will lead to fetal death and form a red mass (fetal resorption) because of no more totipotential properties of the cells [28]. That is why, when fetal damage occurred during this period, it could not be repaired and neither further developed. This condition is one of teratogenic indication of an agent $[25,28,33]$, as also seen this study.

Treating the mice during the third period of pregnancy produce interesting results. All animals in the treated groups were pregnant. Even though the number of the fetus in the treated animal was decreased significantly compared to control animals, the pregnancy developed faster, especially those treated with $10 \mathrm{mg} / \mathrm{kg}$ BW butanol fraction. In this situation, mice treated with butanol fraction of $C$. filiformis produced as many as 10 fetuses, compared to those by control mice of 14. According to McLaren and Michief [34], the number of fetus affects the increase in BW of mice. If the number of the fetus is higher, the parent $\mathrm{BW}$ will also be higher.

The dose-response relationship found in this study is not linear. Calabrese and Baldwin [35] described that the nature of the dose of the response generated is not something linear that allows a U-shaped doseresponse relationship, often called biphasic or hormesis. This effect is often found in the fields of pharmacology and toxicology [36]. The effect is may due to several factors, such as antagonistic effects of the mixture compounds available in the fraction, compounds that have different target and mechanism of action as well as their pharmacokinetic profiles, etc., that may need to further investigation.

From the above explanation, it can be concluded that the butanol fraction of $C$. filiformis produced infertility and deliberate pregnancy development and fetal defect on mice.

\section{ACKNOWLEDGMENT}

We are very grateful to the rector of Universita Andalas for supporting this publication through the DIPA budgeting project.

\section{REFERENCES}

1. Kumari R. A review on the standardization of herbal medicines Int $\mathrm{J}$ Pharm Sci Res 2016;7:98.

2. Indonesian Ministry of Health. National Policy of Traditional Medicine; 2007. Available from: http://www.binfar.depkes.go.id/dat/ lama/1206328790_Buku\%20Kebijakan\%20Obat\%20Tradisional\%20 Nasional\%20Tahun\%202007.pdf. [Last accessed on 2018 Sep 05].

3. Nelson SC. Cassytha filiformis, Plant Disease. Hawaii: Cooperative Extension Service; 2008.

4. Mythili S, Gajalakshmi S, Sathiavelu A, Sridharan TB. Pharmacological activities of Cassytha filiformis: A review. Asian J Plant Sci Res 2011;1:77-83.

5. Quetin-Leclercq J, Hoet S, Block S, Wautier MC, Stévigny C. Studies on Cassytha filiformis from Benin: Isolation, Biological Activities and Quantification of. Benin: In Proceedings of Bioresources Towards Drug Discovery and Development; 2004. p. 81-107. 
6. Adonu CC, Esimone CO, Attama AA, Ugwueze MC. In vitro evaluation of anti bacterial activity of extracts from Cassytha filiformis linn against urogenital clinical gram-negative bacteria. Int J Pharm Biol Sci 2013;3:99-107.

7. Armenia A, Yuliandra Y, Sattar MZ. Comparative effectiveness of defatted hypotensive crude extract, ethyl acetate and butanolic fractions of Cassytha filiformis L. On different models of hypertensive rats. World J Pharm Pharm Sci 2014;3:200-8.

8. Yuliandra Y, Armenia A, Arifin H. Antihypertensive and antioxidant activity of Cassytha filiformis L.: A correlative study. Asian Pac J Trop Biomed 2017;7:614-8.

9. Armenia. Efek Ekstrak Butanol Tali Putri sebagai Antikoagulan Pada Mencit Putih Jantan. Padang: Universitas Andalas; 2007.

10. Sahu RK, Roy A, Kothiya S, Maurya AK, Kumar R. Screening of antipyretic and analgesic potential of ethanol extract of Cassytha filiformis leaves. Res J Sci Technol 2012;4:129-31.

11. Babayi HM, Udeme JJ, Abalaka JA, Okogun JI, Salawu OA, Akumka D, et al. Effect of oral administration of aqueous whole extract of Cassytha filiformis on haematograms and plasma biochemical parameters in rats. J Med Toxicol 2007;3:146-51.

12. Armenia A, Alen Y, Ismed F, Yuliandra Y, Fitria AR. Blood sugar lowering effectiveness of Cassytha filiformis fractions on diabetic mice. Res J Pharm Biol Chem Sci 2016;7:1142-7.

13. Tsai TH, Wang GJ, Lin LC. Vasorelaxing alkaloids and flavonoids from Cassytha filiformis. J Nat Prod 2008;71:289-91.

14. Raj B, Singh SD, Samual VJ, John S, Siddiqua A. Hepatoprotective and antioxidant activity of Cassytha filiformis against CC14 induced hepatic damage in rats. J Pharm Res 2013;7:15-9.

15. Karemore MN, Avari JG. Herbal medicines used during pregnancy, childbirth and postpartum care. Int J Pharm Sci Res 2017;8:5326-35.

16. Gholami M, Moallem SA, Afshar M, Amoueian S, Etemad L, Karimi G, et al. Teratogenic effects of silymarin on mouse fetuses. Avicenna J Phytomed 2016;6:542-9.

17. Armenia A, Hercegovina H, Gustinanda D, Salasa AN, Yuliandra Y, Ismed F. Acute and delayed toxicity study of Cassytha filiformis defatted extract. World J Pharm Pharm Sci 2015;4:155-62.

18. Yuliandra Y, Arief R, Jannah MH, Arifin H. Reversible hepatotoxicity of Cassytha filiformis extract: Experimental study on liver function and propofol-induced sleep in mice. Pharm J 2019;11:69-74.

19. Yuliandra Y, Armenia N, Salasa AN, Ismed F. Subchronic toxicity of ethanolic extract of Cassytha filiformis L. on the renal function of rat. J
Sains Farm Klin 2015;2:54-9.

20. WHO. WHO Traditional Medicine Strategy 2014-2023. Geneva: World Health Organization; 2013

21. Conour LA, Murray KA, Brown MJ. Preparation of animals for research issues to consider for rodents and rabbits. ILAR J 2006;47:283-93.

22. BPOM. Pedoman Uji Toksisitas Nonklinis Secara In vivo. Jakarta: Badan Pengawas Obat dan Makanan Republik Indonesia; 2005.

23. Almahdy A. Teratologi Ekperimental. Padang: Universitas Andalas Pers Padang; 2012.

24. Bronson FH. The estrous cycle. In: Bronson FH, editor. Mammalian Reproductive Biology. Chicago IL: University of Chicago Press; 1989. p. $67-75$

25. Little BB. Drug and Pregnncy. Great Britain: Hodder Arnold; 2006.

26. Prasad GJ, Kalyani DC, Prakash GC. Teratogenicity: A mechanism based short review on common teratogenic agents. Asian Pac J Trop Dis 2014;4:421-32.

27. Sadler LD. Lagman's Medical Embryology. $25^{\text {th }}$ ed. Philadelphia, PA: Wolters Kluwer Health; 2012.

28. Morrison JL, Regnault TR. Nutrition in pregnancy: Optimising maternal diet and fetal adaptations to altered nutrient supply. Nutrients 2016;8:E342.

29. Bánhidy F, Lowry RB, Czeizel AE. Risk and benefit of drug use during pregnancy. Int J Med Sci 2005;2:100-6.

30. Vonnahme KA, Lemley CO, Caton JS, Meyer AM. Impacts of maternal nutrition on vascularity of nutrient transferring tissues during gestation and lactation. Nutrients 2015;7:3497-523

31. George P. Concerns regarding the safety and toxicity of medicinal plants an overview. J Appl Pharm Sci 2011;1:40-4.

32. Shaw SWS, Cheng PJ, Chang YL, Chao AS, Wang TH, Chang SD, et al. Human amniotic fluid stem cells have better potential in early second trimester of pregnancy and can be reprogramed to iPS. Taiwan J Obstet Gynecol 2017;56:770-4.

33. Harbinson RD. The Basic Science of Poison Cassaret and Doull's Toxicology. New York: Macmillan Publishing Co. Inc.; 2008.

34. McLaren A, Michief D. Super-pregnancy in the Mouse 2. Weight Gain During Pregnancy by Anne McLaren and Donald Michief Royal Veterinary College. London: University of London; 1959.

35. Calabrese EJ, Baldwin LA. Hormesis: U-shaped dose responses and their centrality in toxicology. Trends Pharmacol Sci 2001;22:285-91.

36. Calabrese EJ. Hormesis and medicine. $\mathrm{Br} \mathrm{J}$ Clin Pharmacol 2008;66:594-617. 